\title{
CONCEPT OF THE COMPUTER SCIENCE COURSE AND SOME ASPECTS OF ICT INTEGRATION INTO EDUCATION
}

\author{
Pavel Rosman, Ladislav Buřita
}

\section{Introduction}

In today's dynamic world, there have been major changes in the requirements made on education and professional training. Some branches are emerging and disappearing, and the demand for a certain range of experts is changing. Knowledge is the current source of competitive advantages; managers have to realize that until they don't start managing the knowledge process of their company, they are living in the information economy which is already part of the past. People are being forced to change their specialization and have to study continuously to improve their qualifications.

The paper includes the results of research in teaching Computer Science for Economists (CSE) to prospective economists and managers at the Faculty of Management and Economics (FaME), Tomas Bata University (TBU) in Zlín. It elaborates only on the part of the research goals: to what extent the course meets the expectations of prospective economists and managers for the use in practice and the students result in CSE course. In this paper we raise a question whether students and teachers in tertiary education are adequately prepared to use all the opportunities and approaches leading to effective teaching, particularly in the field of distance learning supported by modern information and communication technology (ICT), which offer new possibilities.

Therefore, we were interested in the student's attitude to this type of education, including their willingness to invest some money in it. As educators, we feel the need to comment on this situation, to address some of the issues and to express our view on this problem of university education. The paper does not cover of all aspects of the tuition CSE at TBU; it presents the basic framework schema of teaching and experience of tutors, result of the research in the education concept and discussion for the father improvement of the CSE.

\section{Knowledge Society and ICT Integration in Education: Literature Review}

The chapter characterizes the knowledge management in the knowledge society and the aspect of the information and communication technologies (ICT) integration into education. There are mentioned culture and study culture with respect to the ICT using in education process; some ICT tools are described.

\subsection{Knowledge Society and Knowledge Management with ICT Support}

Towards knowledge society is dependent on exploring its aim and content. It is necessary to initiate the study of knowledge, knowledge strategy preparation and implementation of knowledge management practices. Knowledge is one of the strategic resources of the organization and Its classification has a significant impact on the practical implementation of activities related to knowledge management. The classical division of knowledge into explicit, implicit and tacit can serve as an illustrative example. Knowledge of the various classifications and their use affects the process of creating a knowledge-based strategy. It determines the style of knowledge management that will prevail in the organization. Simultaneous use of several classifications of knowledge at the same time we can 
provide a comprehensive approach to knowledge management, which is necessary during the implementation phase. Thus we also solve the long-lasting confrontation between managerial and technological perspective of knowledge management [3].

Because the natural resources and cheap labor force depleted, the developed countries are increasingly focused on commercial exploitation of knowledge and skills of people in organizations. Many companies are beginning to feel that the knowledge of the employees is the most valuable asset. Knowledge management began to reach out to workers as philosophical as well as technological level, as the debate on how knowledge should be managed on a daily basis and used as efficiently as possible. Knowledge management in organizations brings to the company a lot of problems and issues. Reasons to measure the investment in knowledge are many. Among the most important are the efficiency of investments, management and control of personnel and feedback learning. Mapping organizational knowledge is one of the tools for recording and coordination skills. Mapping knowledge flows in contrast to the numerical index includes humans. This mapping obviously has its advantages and disadvantages. Other differences arise from the mapping of explicit and tacit knowledge [15].

The knowledge economy phenomenon raises a number of questions. There are some opinions that it is the beginning of a new global civilization transformation. But also they can meet with a dismissive attitude for which this concept is just old fashion naming to well-known processes. These trends are a source of permanent qualitative transformation of the company, to the capital growth of the use of knowledge capital. Given the transformations that have taken place in the economic environment, businesses are forced to find new methods of management knowledge-capital enterprises which form a significant part of the total capital of the company [2].

The knowledge management in companies is an object of the set of research studies, for example [16]. The crucial factors for companies that want to succeed in the global competition are knowledge and abilities to use the knowledge in the best possible way. With the growing need of knowledge, significance of knowledge management grows, as well as tools of knowledge management in organizations. The research was focused on finding what leads companies to be interested in knowledge management and what phase of its use they find themselves in; the second area was oriented on the corporate environment as a tool for support of acquiring and sharing of knowledge, and the last part of the research was interested in methods and particular procedures used in companies, which could be taken advantage of in connection with the implementation of knowledge management.

As it followed from the research results, the companies are interested in knowledge management, but they come across many obstacles, which finally discourage them from its consistent implementation. Within the horizon of three years, companies plan to deal with knowledge management much more intensively and even to remove potential barriers of its introduction. It can be stated that companies consider knowledge management a significant tool for increasing their competitive ability [16].

Knowledge society is tightly connected with the learning processes, it is mentioned the term of "learning organization" The learning organization is characterized by the active steps in creating new business strategies to be successful and where there is constant communication training and development give it the competitive edge and individual employee is career resilient. That is why learning is good for both individual and organization. An organization, which achieves the standard of learning organization, will have employees with positive attitudes because they are seen as a vital ingredient in reaching shared business goals. Learning in the learning organization means active and everlasting learning from own work, work of our colleagues and competitors. Withal it is going especially about the change of corporate culture [14].

During the last decades of the twentieth century, the technological development has brought new means of communication and a global information infrastructure. This infrastructure allows a faster creation, processing, transfer and storage of huge amounts of information. Internet has driven the increase of collaboration, learning and research, electronic commerce and oneclick information. Nowadays Internet is the backbone of the new economy, enabling business communication strategies like Business-to- 
Business (B2B), Business-to-Customer (B2C), and Business-to-Employee (B2E) [7].

ICT is an important tool for manager's decision support, but it doesn't mean that they are a source of competitive advantage. ICT are mostly part of every system and subsystem inside a company or organization. However, nowadays they are a commodity and no longer a source of competitive advantage. Knowledge is the current source of competitive advantages; managers have to realize that until they don't start managing the knowledge process of their company, they are living in the information economy which is already part of the past. Investment on information technologies has to have a complete strategy of application in a mid-term, otherwise it can be waste of money. Investment on information technologies has to have a complete strategy of application in a mid-term, otherwise it can be waste of money. The new possibilities of easier and faster access to information has changed the way the whole world moves forward, starting from individuals, the way the communicate, the way they buy, the way products are bought, produced and offered and in the end changing societies, markets, companies, etc. [11].

The sociotechnical systems recognized many years ago that organizations functioned most effectively when their social and technological networks were compatible. This is the case exactly with e-learning systems. On the other hand, information systems can focus not only on the internal activities, but also the external ones. They can connect customers or suppliers to the company's database [10]. Regarding the needs of information and data storage, different information systems are commonly known [21].

\subsection{ICT Integration in Education Process}

Culture is the product of the shared values, beliefs, priorities, expectations and norms that serve to inform the way in which an organization manifests itself to the world. The basic idea of culture, including school culture, is that it consist of shared meanings and common understanding, and this culture is variable from school to school [8].

School culture includes everything in school surroundings that is made by human beings, consisting of tangible items as well as intangible concepts and values. The basic idea of culture including school culture is that it consists of shared meanings and common understanding, and that this culture is variable from school to school. In the Czech Republic the first model of school culture was created by Světlík [22].

This model is being used as a basic model of school culture in courses for headmasters in the Czech and Slovak Republic, too. The model of school culture helps us to understand schools better. We underline that for schools are their mission and their orientation to teaching and learning process (preparing young people for living in present and in future society) very important [9].

Information and knowledge society requires computer and information literate citizens. It is doubly true for university graduates [13]. Without sufficient understanding of the topics, including self-practice examples, the role of the teacher - consultant (resp. a tutor in terms of elearning courses) is indispensable. Ignoring the learning process while designing and developing e-learning systems leads to management information systems (MIS), which are important in managing educational institutions activities and help educational institutions achieve a mature level of automation, but are not themselves learning-focused systems [5].

Education today is under pressure from various views and reforms, which are often contradictory. Recently, we have accepted many educational models, teaching strategies, teaching concepts and methodologies in the Czech education system [1], [24]. New concepts in much revived and enriched Czech education with introducing useful challenges: personalized learning, the possibility of greater choice and availability of educational materials including study materials for distance learning. At the same time, however, the instruction (not only at universities) rejected numerous wellestablished methods and techniques [11]. Technological innovations are often considered more important than conceptual changes; and thus teaching becomes dehumanized [7].

An interesting research was oriented at the ICT specialists preparation at Czech universities with respect to the needs of the companies and organizations [6]. The university graduates analysis was focuses on universities effective in the ICT education area and compares their 
study programs with requirements of businesses. It describes typical "product" of Czech education process in the area of ICT skills. General conclusions show that majority of graduate bachelors (at about 85\%) in the Czech Republic do not have knowledge profile to enter business as qualified employees without expensive additional training. At master level the same applies for at about $40 \%$ of graduates. Results from our research confirmed positive trends in education of ICT at universities in the Czech Republic. This is valid for both types of study program (bachelor and master study program). The distance between the student's knowledge and business requirements are smaller. This could be cause for example by advances in the study programs structures and courses that are provided in selected study programs.

There are examples that the ICT integration in education process was with problems at all levels of education systems. The main focus of the article [18] was on the perceptions of educational practitioners (at the lower secondary level) regarding obstacles that seriously impede the realization of ICT-related goals of schools. The results were from a worldwide survey among national representative samples of schools from 26 countries. The article contains a short summary of the design of this project, a review of main indicators regarding ICT in elementary and lower secondary schools, main obstacles and an exploration of the co-variation between obstacles and contextual factors at the country-level.

ICT is very quickly developed branch that offers for data, information, and knowledge processing the many approaches and tools, see Figure 1 [9]. Data processing is more than 40 years supported by Database Management Systems (DBMS) and education in databases (DB) is a long traditional part of the education not only for the ICT oriented students. The DBtechnology failed for the effective decision support and it leads to the Business Intelligence technology (about 20 years ago), supported by Data Warehousing (DW), Online Analytical Processing (OLAP). The institutional result of the decision support offers Managerial IS (MIS) and DSS (Decision Support Systems) for the middle management; for the top management was developed Executive IS (EIS). Priority of knowledge processing is the task the last 20 years, too. There are developed Knowledge Management Systems and Expert Systems (ES) as a part of the Artificial Intelligence (Al). These systems are challenge for the university teacher to bring them into the curricula.

\subsection{ICT Tools for Education Support}

Current university information systems (IS) support data and information processing, sharing and storage; knowledge and wisdom are connected with human action and ethics; and it is precisely it, knowledge, what needs to be managed with the help of ICT, as information is no longer providing a competitive advantage. Learning management systems (LMSs) are responsible for "learning" activities, while university management information systems (UMISs) are responsible for handling University managerial activities. LMSs can't provide the managerial functions needed to support universities, and UMISs don't support the "learning" process [9]. Both systems have to integrate and operate together to support educational institutions and e-learning. Managing universities activities requires a university management information system. UMIS refers broadly to a computer-based system "collection of hardware, software, people, data, and information" that provides managers with the tools for organizing, evaluating, and efficiently running their departments. Examples of UMIS components include a student IS, a librarian IS, a faculty IS, and an economy (finance) system, as illustrated in Figure 2.

\section{Fig. 1: IS focused on internal activities}

\begin{tabular}{|c|c|c|c|}
\hline Data & Information & Knowledge & Wisdom \\
\hline $\begin{array}{c}\text { DW, DB } \\
\text { DBMS }\end{array}$ & & & \\
\hline & LAP & & \\
\hline & $\begin{array}{c}\text { DSS, } \\
\text { MIS, EIS }\end{array}$ & & \\
\hline & \multicolumn{2}{|c|}{$\mathrm{ES}, \mathrm{Al}$} & \\
\hline
\end{tabular}

Source: [9] 


\section{Fig. 2: Model UMIS}

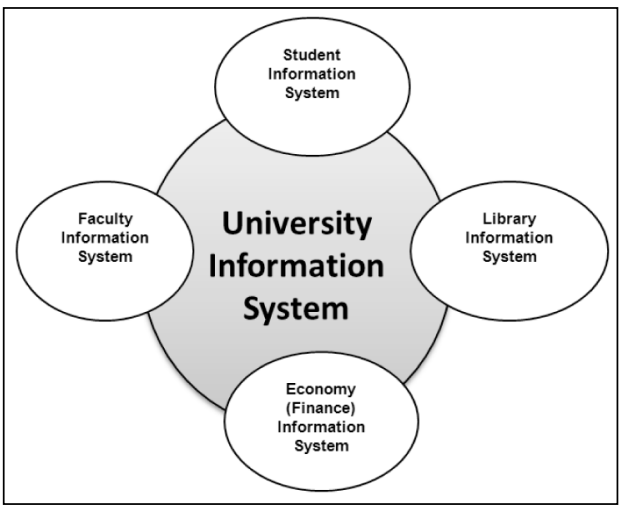

Source: [9]

Portal technologies are going through time of upheaval in their development. Exponential increases in information and sources on the web require sophisticated portal solutions. Key characteristics of a successful portal and the standard portal services are described in [5], [12]. Elaborated portal solutions which are technologically advanced are essential prerequisites for a website success, but it is always necessary to keep in mind the key aspect of website success which is a customer aspect [2].

Each form of education provides a suitable space for the development of certain styles of learning. Teaching with computers has been employed for a long time. Teaching by e-learning is nothing new either. Personalized education lessons tailored to a student, adaptable according to theirs qualities is becoming popular. In the long term, a discussion has been held on what kind of content such a course should have [13]. They have been taken in steps of information management that involves information sources and instructions for students, organization of education, communication between lecturers and students, techniques of the student's evaluation and administration of the study results. E-learning as the "learning" process revolution enabled by new technologies that, hopefully, will present an effective and efficient learning process that doesn't exist today. The question of implementing this type of study includes both the availability of adequate technical support, and the already acquired activities that students are involved in, carried out through ICT [11]. E-learning tends to revolutionize and manage the learning process [5], not only to manage universities.

In that process was applied some steps and parts of the information management that involves information sources and instructions for students, organization of education, communication between lecturers and students, techniques of students evaluation and study results administration. The current theory of a learning process is based on theories from the learning process. These processes can be divided into:

- Student's learning processes (processes occurring when the student learns).

- Learning environments (in which climate and environment learning takes place).

- Educational activity of a teacher (coordination of learning activities) [19].

The analysis of student's learning styles in included in the articles at the ICTE Conference [5], [9], [13] or in articles [4], [8]. The analysis of teachers' learning styles will be another keystone of defining links between teaching activities and student's learning styles. The task of a teacher is to find a balance in methods and procedures so that each student has the opportunity to develop. The most important task will be to create a learning environment that will promote learning. There is a series of concepts related to teachers' education in the educational literature: teaching style, teaching method, competence, skills, the teacher's approach to teaching, and others [19]. None of the definitions of these terms is accurate enough to be used for the identification and formulation of sub-processes in teaching or even to differentiate between types of teaching styles in relation to student's learning styles [12].

Authors of the paper have been in charge of the CSE course at the FaME for many years. As educators we feel the need to comment this situation, to address some of the issues and to express a view on problem of university education [20]. The key to the improvement of teaching is to explore people's learning styles [8]. If our goal is individualization in teaching, respecting individual particularities of students, we have to make an analysis whether students and teachers in tertiary education are adequately prepared to use all the opportunities and approaches leading to effective teaching, particularly in the field of distance learning supported by modern ICT [12]. 


\section{Research on the Innovation of Approaches to Teaching Computer Science}

The Computer Science for Economists (CSE) course might serve as an example, when a whole range of literature is available on the market as well as plenty of interactive courses on the Internet [7]. Although the paper does not cover of all aspects of the CSE course at TBU [24] in favor of enterprise computer science, it presents the basic framework schema of teaching and experience of tutors. Teaching Computer Science responds to the demands of the information society and globalization trends.

The tutors try to improve the course constantly [20], develop the ICT use [12], and thus prepare students in accordance with the requirements of the social environment [4], [20]. To obtain adequate feedback, an extensive research was carried out. It confirmed the correct aiming of the course, but also identified possible areas of improvement. The analysis of the research results makes possible to suggest options for further development of the course. The key to the improvement of teaching is to explore people's learning styles [13]. Let us present the results of the recent research on whether the current form of the CSE fulfils the expectations of the undergraduates.

The research is based on the results of a survey conducted among students of full-time and part-time (combined) form of study at the FaME, TBU in Zlín Based on the evaluation of a questionnaire survey, student opinions on teaching, conducting instruction, approach to testing and ways of examining were gained. The responses were statistically processed, analysed, and will be used to further improve the preparation, content and instruction of the course. The research was carried out at end of semester the academic year 2012/2013.

\subsection{CSE Course - Essential Characteristics}

The main objective of the course CSE still lies in providing an overview of modern ICT, with regard to all the necessary components of information systems and applications, including their essential characteristics. The aim of the course is to provide students with a recent overview in the field of modern ICT. The course is intended to further broaden the knowledge and skills in the field of ICT [13], especially to consolidate them and reach the level required by the university (students have different levels when entering the FaME, since they come from various types of secondary schools). There is a sustained increase in the number of students in the first year of Bachelor's study programme.

In the 2012/2013 academic year, over 460 students were admitted to the first year of Bachelor's study programme FaME, TBU in Zlín. At the beginning of the semester, the students use the university IS to enroll in courses and chose particular seminars and practical exercises in laboratories. Thus they optimize their own study schedule. The objectives and description of the course are stated on the university portal STAG [23] in the course syllabus including course books. Important study materials, assignments, lectures and seminar topics are posted on the education portal. Students access their study materials in the distance learning courses in the LMS Moodle including important study materials, assignments, lectures, guidelines for exercises in laboratories and seminar topics [24]. Furthermore, students have at disposal a large number of sample documents created in OA, and thus they can compare their products to the standards.

\subsection{Methodology of Research and Survey Questionnaire}

At the end of the semester in the academic year 2012/2013 a questionnaire survey of the content, form and quality of the CSE course was carried out. The aim was to gain students' opinions on the course and their evaluation, with the intention to improve the CSE teaching in the future [4], [20]. From a methodological point of view was carried out by an anonymous questionnaire survey using the forms (students) and Internet program (part-time students) for the two groups of respondents:

1. Full-time students (290), of which 245 completed the survey.

2. Part-time students (176), of which 84 questionnaires was returned.

The paper questionnaire (Test 1) contained 13 questions. The questions aimed at obtaining the views on the CSE course, thus they pursued a single goal. Up to 11 items were designed as "closed" (dichotomous) questions, with the option to comment on them. One item was a "closed" 
(dichotomous) question without any comment and one item was an open question.

The processing of the survey web application (Test 2) was based on the design of Tests 1. The questionnaire contained 14 questions in total; 12 of them were designed as "closed" (dichotomous) questions. The students participated in the research in computer laboratories provided with access to the Internet. The content of the questionnaire was adapted to include questions concerning practical training of full-time students. One question was a "yes/no" question and one was an "open" question. This was ensured by 3 questions; the third of them was a question requiring information about the student's tutor.

The questions were not very demanding; the prerequisite was the attendance at lectures and completion of the assignment. The success of obtaining the completed questionnaire was ensured by the fact that the questions were distributed during the exam. This also influenced the research results because it addressed only the students who attended the course by the examination date. The completion of both questionnaires did not exceed 15 minutes, which is consistent with the theory [17]. The spreadsheet tool was applied to the evaluation of questionnaire (Test 1) and SW tool (Test 2); the aggregation operations (summation, average) were processed and the result charts were created.

The questionnaires within Test 1 and Test 2 were similar in content. Both sought to determine how the students perceived the CSE course instruction. Test 1 was more detailed and offered more open questions. Test 2 included questions about practical training and was designed in a way which forced the students to react to each question; only then were they allowed proceeding further. The preparation of test 2 in the web application form took some extra efforts. On the other hand, the evaluation of the survey including the full-time students was carried out continuously and was easier (it was automated in the application). The evaluation of the survey including part-time students could be commenced only after gathering all the answers and was quite demanding. The credibility of the answers in Test 1 was guaranteed by distributing the questionnaire forms to selected respondents only and collecting them after passing the examination. In Test 2 it was not guaranteed that some respondents did not fill in the questionnaire more than one times.

\section{Evaluation of Research}

The part-time students were evaluated lecturers, who jointly taught the course. A total of 84 students handed in the questionnaires; 57 students indicated a favorable rating of "satisfied" and "very satisfied" (21), 5 students were "somewhat dissatisfied". There was one case of the "dissatisfied" option. The students expressed reservations about the repetition of certain concepts and terms, then the pace of going through the teaching material, occasionally tedious and boring explanations.

The research into innovation in teaching of the CSE course contains statistics on the responses of individual questions of the questionnaires. In line with the objective of this article, the concern here is to deal with the benefit of lectures to students only. Numerous aspects were evaluated, including comments on the instruction, structure and content of lectures and practical exercises, the attractiveness of presentations, teaching approach, etc. Of the total number of 245 full-time students who filled and handed in the questionnaire, 121 students reported that they were 'satisfied' and 98 students selected the "quite satisfied" option. "Somewhat dissatisfied" was chosen by 19 students and 7 cases of the "dissatisfied" option. Final evaluation compares the results of both tests. The vast majority of students selected a favorable rating of "satisfied" and "very satisfied".

These include the following areas:

- Benefits of lectures to students and the difficulty of the course.

- Quality of the lectures.

- Organization of the course.

- Teacher - student communication.

- Assignments, source materials and the difficulty of the course.

- Testing and examining in the course.

The evaluation of the satisfaction with the course content by the full-time students is shown in Table 1, the evaluation by the parttime students is shown in Table 2. In line with the objective of this article, the concern here is to deal with the benefit of lectures to students only. Numerous aspects were evaluated, including comments on the instruction, structure and content of lectures and practical exercises, the 
attractiveness of presentations, teaching approach, etc. The vast majority of students (see statistics) selected a favorable rating of 'satisfied' and 'very satisfied'. Of the total number of 245 students who filled and handed in the questionnaire, 121 students reported that they were 'satisfied' and 98 full-time students selected the "quite satisfied" option. "Somewhat dissatisfied" was chosen by 19 students and 7 cases of the "dissatisfied" option.

\begin{tabular}{c|c|c|c|c} 
Tab. 1: & \multicolumn{4}{|c}{ Evaluation of full-time students } \\
\cline { 2 - 5 } Option & \multicolumn{4}{|c}{ Full-time students } \\
\cline { 2 - 5 } & satisfied & $\begin{array}{c}\text { quite } \\
\text { satisfied }\end{array}$ & $\begin{array}{c}\text { somewhat } \\
\text { dissatisfied }\end{array}$ & dissatisfied \\
\hline Quantity & 121 & 98 & 19 & 7 \\
\hline
\end{tabular}

Source: own research

\begin{tabular}{c|c|c|c|c} 
Tab. 2: & \multicolumn{4}{|c}{ Evaluation of part-time students } \\
\cline { 2 - 5 } Option & \multicolumn{4}{|c}{ Part-time students } \\
\cline { 2 - 5 } & satisfied & $\begin{array}{c}\text { quite } \\
\text { satisfied }\end{array}$ & $\begin{array}{c}\text { somewhat } \\
\text { dissatisfied }\end{array}$ & dissatisfied \\
\hline Quantity & 57 & 21 & 5 & 1 \\
\hline
\end{tabular}

Source: own research

Generally, among the most frequent features which gained positive evaluation from full-time students of the CSE course were: open and friendly attitude, ability to explain specialized subject matters in a comprehensive way, clarification of setting important dates, providing all study materials and additional materials in electronic form, professional and outgoing approaches and ability to capture students' attention.

\subsection{Subject Areas - Outcomes}

In both tests, the benefit of the CSE course subject areas was examined in detail. Individual subject areas were marked; the average mark in test 1 is 1.98 (1.68 is the best and 2.14 the worst one); the average mark in test 2 is 2.27 ( 1.80 is the best and 2.76 the worst one), see Table 3. The least beneficial subject areas marked by the students were areas 3 and 7 ; the full-time students identified areas 3, 6, 7 and 8 . The subject area which also includes the issues of enterprise computer science earned the average mark of 1.97 by the part-time students and 2.50 by the full-time students. Regarding the fact that lectures at the FaME, TBU are not mandatory, students' attendance was decreasing steadily from almost $100 \%$ at the beginning of the course to less than a half. The full-time students lacked motivation to participate in lectures, and therefore they challenged the benefits and importance of the lectures. They expressed more criticism; however, it is vital to state here that they have less or no practical experience in the use of ICT in practice. They have not been able to assess the importance of the course in view of the future needs so far, and thus their marks were lower than the marks suggested by the part-time students.

The most frequent reasons of the quite favorable opinions expressed by the part-time students include: expert knowledge, active approach to teaching, high-quality and rigorous preparation for consultations, professionalism, ability to attract students' attention, sufficient amount of documents and study materials in electronic form, sufficient amount of the information available, including date scheduling and stating clear requirements at the beginning of the semester. Among the objections raised were an absence of practical exercises (which were replaced with practical examples), the range of topics and a small number of consultation hours (earlier 20 , now only 10 hours).

\subsection{Benefits of Lectures to Students and the Difficulty of the Course}

In both tests, the benefit of the CSE course subject areas was examined in detail. Individual subject areas were marked; the average mark in test 1 is 1.98 (1.68 is the best and 2.14 the worst one); the average mark in test 2 is 2.27 ( 1.80 is the best and 2.76 the worst one), see Table 3. The least beneficial subject areas marked by the students were areas 3 and 7 ; the full-time students identified areas 3, 6, 7 and 8 . The subject area which also includes the issues of enterprise computer science earned the average mark of 1.97 by the part-time students and 2.50 by the full-time students.

Table 3 shows the result of the responses about the importance of the CSE subject areas for students. 
Tab. 3: Importance of the CSE subject areas for students

\begin{tabular}{c|l|c|c} 
Order & CSE subject area & Part-time students & Full-time students \\
\hline 1 & Introduction, CSE placement test & 1.68 & 2.16 \\
\hline 2 & Computer science as a scientific discipline, basic concepts & 1.92 & 2.41 \\
\hline 3 & Information and Knowledge Society & 2.14 & 2.76 \\
\hline 4 & Data, information. Codes and data compression & 1.83 & 2.24 \\
\hline 5 & Software & 1.80 & 2.27 \\
\hline 6 & Technical means of data processing & 1.98 & 2.49 \\
\hline 7 & Computer components & 2.13 & 2.46 \\
\hline 8 & Information systems and enterprise application software & 1.97 & 2.50 \\
\hline 9 & Computer networks, Internet and network services on the Internet & 1.68 & 2.00 \\
\hline 10 & Computer infiltration, malware & 1.77 & 1.80 \\
\hline 11 & Computer security and data protection, cryptography & 1.93 & 2.08 \\
\hline & Average & 1.89 & 2.27 \\
\hline & & & Source: own research
\end{tabular}

Table 4 shows the result of the responses. The vast majority of students consider the subject's areas appropriate. The question of the appropriateness of the choice of subject areas presented in lectures was assigned to the fullparts students only. The result has met the expectations; it shows a normal distribution in which the peak in the part-time students is shifted to a higher degree of difficulty, which corresponds with the distance from the teaching of ICT (which could not have such a standard and importance in the past as it has now). The difficulty of the course for students in the range from challenging, demanding, mean and easy (scale of $A, B, C, D$ ) was assessed as a percentage:

- Part-time students (test 1): 23; 59; $12 ; 6$.

- Full-time students (test 2): 5.5; 31.5; 48; 15.

These measures should make work more effective and facilitate communication between lecturers and students. The knowledge and experience stemming from this research opens up space for more effective implementation of e-learning. The attempt to clarify this confusion is an idea to implement a prototypical e-learning model.

\section{Tab. 4: Importance of the CSE subject areas for full-time students (count of the responses)}

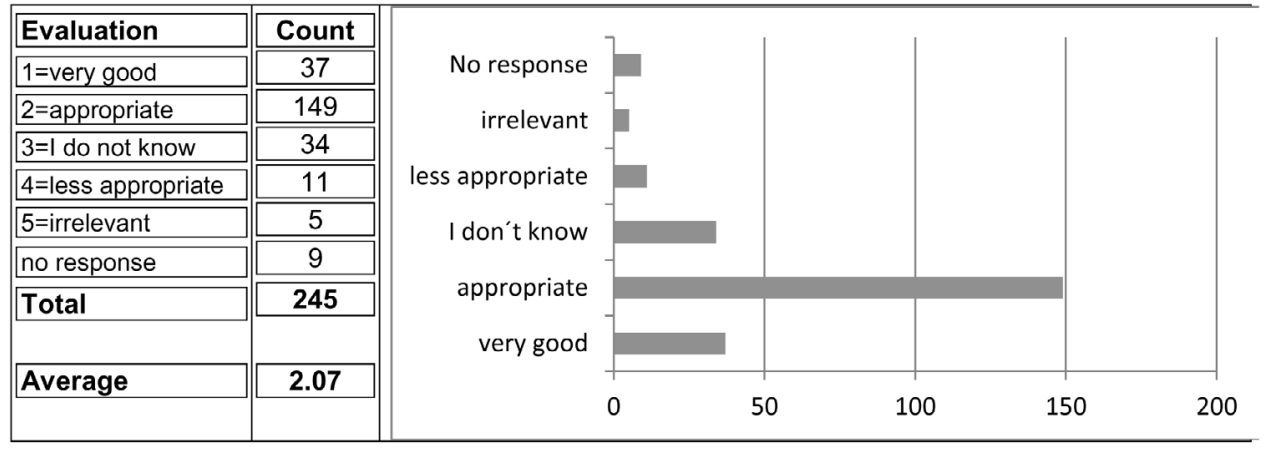

Source: own research 


\section{Questionnaires Evaluation for the Future Course Improvements}

The CSE course is intended to further broaden the knowledge and practical skills of students in computer science. Based on the evaluation of both questionnaires and the conclusions that emerged from the respondents' opinions of both forms of studies, the following conclusions and recommendations are suggested:

- To task students, both at practical exercises and seminars, and at lectures.

- To promote autonomy in obtaining necessary information (IS STAG, TBU FaME).

- To update the content of courses continuously and to include more practical examples into lectures to maintain the assessment of course credit work and final test, including testing.

- To communicate important information with appropriate comments already at the introductory lecture and to focus on what is essential and important for the study.

- To stimulate students by raising questions during, tutorials and practical exercises.

- To place emphasis on independent work during practical exercises (full-time form of study) and self-study (part-time form of study).

The teaching should reflect the requirement for getting the ICT skills of students from various schools on the same level, preparing them for work with ICT at the FaME, and enhancing the professionalism of work with ICT for enterprise computer science. Based on the evaluation, it must be regularly to updating the current form of the CSE course. It is important to respect different forms of study (full-time and part-time) and to adapt the content and form of lectures to them to maintain the current organization of the course, including testing and final evaluation of students. The outcomes have brought the following ideas into focus of attention:

1. From the methodological point of view, it is essential to lead and motivate students.

2. Active participation on the side of students is considered a common requirement.

The goal is to make this piece of research available to students and e-learning researchers, so we can together overcome this confusion and start focusing on the "learning" process as the main asset of "e-learning." It is necessary to post the vital and important information on the information sources, where it is accessible and easily obtainable to each student via the internet, and thus to eliminate data redundancy [2], [11].

\section{Conclusion}

Knowledge is the current source of competitive advantages; managers have to realize that until they don't start managing the knowledge process of their company, they are living in the information economy which is already part of the past. Although the paper does not cover of all aspects of the CSE course at TBU in Zlín in favor of enterprise computer science, it presents the teaching framework schema and experience of tutor. The next stage of the research will be focused on finding the opinions of the guarantors and educators who are in charge of selected follow-up courses, or the courses which draw upon the above-mentioned course, assuming a certain degree of information competence.

The FaME superiors repeatedly open the debate of whether it is necessary for faculty students to complete the CSE course. They argue that the knowledge and skills students bring from the secondary school. Teachers primarily refer the counter- argument from the experience of teaching (the research described in the article, too) and in particular the statistics of the results in the course, that every year about $40 \%$ of the students failed and the trend is still deteriorating. Teachers patiently explain that it is not the pure computer science, but the focus of informatics to support the business, which gives our graduates a competitive advantage.

In addition, the unification of the knowledge and skills of faculty students is a result of the course and students mastering for using ICT in studies and in practice. Progressive trend of our teaching in the CSE course is the transition from the interpretation of ICT components to use of ICT services. Teachers try with the maximum use of the results of educational research to improve teaching and content of the subject CSE.

\section{References}

[1] BARTOŠ, P. Základy znalostní ekonomiky. E+M Ekonomie a Management. 2006, Vol. 9, Iss. 4. ISSN 1212-3609.

[2] BRDIČKA, B. Role internetu ve vzdělávání. ICT a kvalita vzdělávání [online]. 2003 [cit. 2010-05-18]. Available from: http://it.pedf.cuni.cz/ bobr/role/ka92.htm. 
[3] BUREŠ, V. Klasifikace znalostí, znalostní strategie a styly znalostního managementu. E+M Ekonomie a Management. 2004, Vol. 7, Iss. 1. ISSN 1212-3609.

[4] BUŘITA, L., ROSMAN, P., TEJKL, R. Preparation of economists and managers for enterprise computer science. Systémová integrace. 2010, Vol. 17, No. 3, pp 46-56. ISSN 1210-9479.

[5] ČERNÁ, M., POULOVÁ., P. User Testing of Language Educational Portals. E+M Ekonomie a Management. 2009, Vol. 12, Iss. 3, pp. 104-116. ISSN 1212-3609.

[6] DOUCEK, P., MARYŠKA, M., NOVOTNÝ, O. Analýza souladu obsahu ICT studijních oborů s požadavky praxe v České republice. E+M Ekonomie a Management. 2013, Vol. 16, Iss. 3, pp. 148-161. ISSN 1212-3609.

[7] DRUCKER, P. Management Challenges for the 21st Century. New York: Harper Business, 1999. ISBN 08-8730-998-4.

[8] EGER, L. Application of the Corporate Culture in Field of School Management. E+M Ekonomie a Management. 2010, Vol. 13, Iss. 3, pp. 26-31. ISSN 1212-3609.

[9] El-GHAREEB, H.A. E-Learning and Management Information Systems: Universities Need Both. eLearn Magazine [online]. 2009, No. 9 [cit. 2014-03-18]. Available from: http://elearnmag. acm.org/featured.cfm?aid=1621693.

[10] GÁLA, L. a kol. Podniková informatika. 2. vyd. Praha: Grada Publishing, 2009. pp. 226-231. ISBN 978-80-247-2615-1.

[11] JIRKOVSKÝ, J., et. al. Role moderních technologií v současné společnosti. In Současnost budoucnost krizového rízení. Praha: T-SOFT, 2007. ISBN 978-80-254-0727-1.

[12] Konstruktivismus v praxi vysokých škol [online]. Západočeská univerzita v PIzni, c2013 [cit. 201403-18]. Dostupné z: http://www.konstruktiv.zcu.cz. [13] KRIČFALUŠI, D. New Concept of ICT Development in Education. In Proceedings Information and Communication Technology in Education. Ostrava: Pedagogic Faculty, OSU Ostrava, 2009. pp. 42-48. ISBN 978-80-7368-459-4.

[14] KRESLOVÁ, P. Učení v učíci se organizaci. E+M Ekonomie a Management. 2003, Vol. 6, Iss. 1. ISSN 1212-3609.

[15] KRÝDLOVÁ, B., NOVÁKOVÁ, P., SKALICKÝ, J. Knowledge Management - Theoretical Framework and Practical Research. E+M Ekonomie a Management. 2005, Vol. 8, Iss. 1. ISSN 1212-3609. [16] MAREŠOVÁ, P. Výzkum uplatnění znalostního managementu v českých podnicích. E+M Eko- nomie a Management. 2010, Vol. 13, Iss. 1, pp. 131-144. ISSN 1212-3609.

[17] PAVLICA, P. a kol. Sociální výzkum, podnik a management: průvodce manažera $v$ oblasti výzkumu hospodářských organizací. 1. vyd. Praha: Ekopress, 2000. ISBN 80-86119-25-4.

[18] PELGRUM, W.J. Obstacles to the integration of ICT in education: results from a worldwide educational assessment. Computers \& Education [online]. 2001, Vol. 37, No. 2 [cit. 2014-01-23], pp. 163-178. Available from: http://www.journals. elsevier.com/computers-and-education/.

[19] ROSENBERG, M.J. Building successful online learning in your organization. New York: McGraw-Hill, 2001. 344 p. ISBN 0-07-136268-1.

[20] ROSMAN, P., BUŘITA, L. The Role of Information Management and ICT in University Education. In Proceedings ICT in Education ICTE'2012. Ostrava: Pedagogical Faculty, OSU Ostrava, 2012. pp. 31-40. ISBN 978-80-7464-135-0.

[21] SODOMKA, P. Informační systémy v podnikové praxi. 1. vyd. Brno: CP Press, 2006. ISBN 80-251-1200-4.

[22] SVĚTLÍK, J. Marketingové ř́zení školy. 1. vyd. Praha: ASPI, 2006. ISBN 80-7357-176-5.

[23] Univerzita Tomáše Bati ve Zlíně. Univerzitní IS STAG [online]. Zlín: Univerzita Tomáše Bati, c2014 [cit. 2014-03-18]. Available from: http://portal. utb.cz/wps/portal.

[24] Univerzita Tomáše Bati ve Zlíně. Studijní portál VÝUKA [online]. Zlín: Univerzita Tomáše Bati, c2014 [cit. 2014-03-18]. Available from: http://vyuka. fame.utb.cz.

Ing. Pavel Rosman, Ph.D.

Tomas Bata University in Zlín Faculty of Management and Economics Department of Industrial Engineering and Information Systems rosman@fame.utb.cz

prof. Ing. Ladislav Buřita, CSc.

Tomas Bata University in Zlín Faculty of Management and Economics Department of Industrial Engineering and Information Systems and University of Defence

Faculty of Military Technologies Communication and Information Systems

Department ladislav.burita@unob.cz 


\title{
Abstract
}

\section{CONCEPT OF THE COMPUTER SCIENCE COURSE AND SOME ASPECTS OF ICT INTEGRATION INTO EDUCATION}

\author{
Pavel Rosman, Ladislav Buřita
}

The paper summarizes the experience of teaching Computer Science for Economists (CSE) course at the Faculty of Management and Economics (FaME) at Tomas Bata University (TBU) in Zlín. The paper presents approaches aimed at developing the effectiveness in increasing students' knowledge and analyses just one aspect of the research - the importance of the CSE course for students. It describes methodology and technology support of using information and communication technology (ICT) in teaching full-time and part-time students. The experience of the introduction of new approaches and methods into teaching with the use of ICT is offered. There are mentioned some aspects, connect with the ICT as a knowledge society, knowledge management, learning organisation and education processes, eBusiness, ICT support of business and ICT in education.

The first part of the paper describes the teaching of the CSE course at FaME/TBU. It states the objective, overview of subject areas and methodology of teaching as well as the use of information and communication technologies. The second part contains the results of the research on the CSE course, its importance for students, focusing mostly on enterprise computer science. The tutors try to improve the course constantly, develop the ICT use, and thus prepare students in accordance with the requirements of the social environment.

The analysis of the research results makes possible to suggest options for further development of the course. Although the paper does not cover of all aspects of the CSE course at TBU in favour of enterprise computer science, it presents the basic framework schema of teaching and experience of tutors. The experience of teaching and assessing students' knowledge are summarized. In the future the research will be extended to the guarantors of the subjects building on the results of the ICT teaching.

Key Words: Computer science, student's evaluation, experience, informatics, research, teaching.

JEL Classification: D83, I21, M15.

DOI: 10.15240/tul/001/2014-3-013 